\title{
Restriction of Competition After Termination of Employment Relationships
}

\author{
Dr. iur. Annija Kārkliṇa \\ Faculty of Law, University of Latvia \\ Associate Professor at the Department of State Law \\ E-mail: Annija.Karklina@/u.Iv
}

The article analyses a legal instrument of restriction on competition after termination of employment relationships. The Labour Law of the Republic of Latvia (hereinafter - Labour Law) governs the restriction on professional activity under Articles 84 and 85 . The article views the goal of restriction on competition, agreement forms, validity preconditions, including notions of professional activity and adequate compensation, term of restrictions, applicability preconditions, legal framework of responsibility where the restriction has been violated and reinforcements of liability. The article also outlines parties' rights to unilateral withdrawal from an agreement to restrict competition. with the applied research methods include analytic method (by analysing the legislation and case law), comparative method (comparing regulation of competition restriction in different Member States of the European Union), and an insight was provided into development of regulation of restriction on competition by virtue of historical method.

Keywords: restriction on competition, non-competition clause, employment relationships, employer, employee, termination of employment relationships, term for restriction on competition, adequate monthly compensation, field of activity, unilateral withdrawal from an agreement to restrict competition.

\section{Contents}

Introduction . . . . . . . . . . . . . . . . . . . . . . . . . 159

1. Restriction on Competition After Termination of Employment Relationships -

Notion, Goal and Applicability Preconditions . . . . . . . . . . . . . . . 160

1.1. Notion of Restriction on Competition and Procedure of Entering into Agreement . . 160

1.2. Goal of the Restriction on Competition . . . . . . . . . . . . . . . . 162

1.3. Due Date of the Restriction on Competition . . . . . . . . . . . . . . 164

1.4. Adequate Compensation for Restriction on Competition . . . . . . . . . . . 165

1.5. Notion of the Field of Activity. . . . . . . . . . . . . . . . . . . . . . 169

1.6. Type and Scope of Restriction on Competition . . . . . . . . . . . . . . . 170

1.7. Understanding the Place of Restriction on Competition . . . . . . . . . . 171

2. Consequences from Restriction on Competition Failing to Meet the Statutory Preconditions . . . . . . . . . . . . . . . . . . . . . . . . 171

3. Responsibility for Violation of the Restriction on Competition

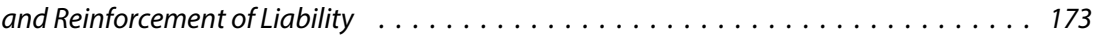

4. Unilateral Withdrawal from the Restriction on Competition . . . . . . . . . . . . . . 177

4.1. Employer's Rights to Unilaterally Withdraw from the Restriction on Competition . . . . 177

4.2. Employee's Rights to Unilaterally Withdraw from the Restriction on Competition . . . 177 


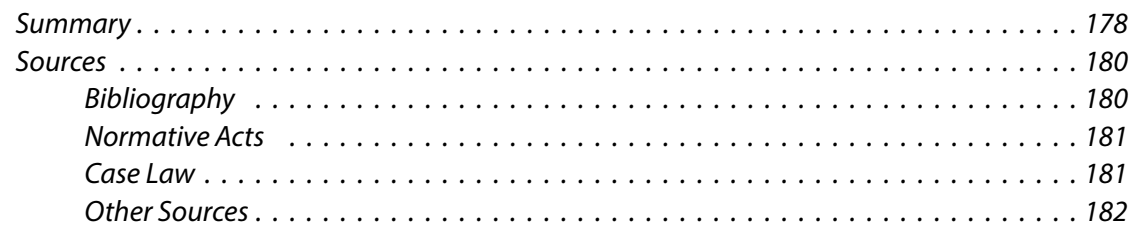

\section{Introduction}

In free market economy when there is often fierce competition between merchants and other employers, any employer finds the necessity for legal means to protecting their economic activities more pressing. An agreement to restrict competition after termination of employment relationships is one of legal instruments of a merchant to achieve that goal.

Like in many other countries, the Labour Law of Latvia since its adoption and coming into force on 1 June $2002^{1}$, regulates the restriction on competition after termination of employment relationships and it has seen several changes over time. The most recent amendments affecting this instrument were made to the Darba likums [Labour Law] in 2017. ${ }^{2}$ Also the case law has gone through changes over time in context of restriction on competition and currently there is no common understanding of all aspects of application of the restrictions on competition.

Over last years, the restrictions on competition were met more frequently in actual life. Most often agreements to restrict competition are signed with employees who work in sales, nevertheless several last years the number of non-competition clauses in technology and construction sector has grown globally. ${ }^{3}$

Over time an understanding of application of this instrument has changed, for example, in German law the restriction on competition was once attributed only to so-called white-collar workers (especially those working in commerce), however, the Federal Labour Court of Germany in its judgment of 1990 decided to attribute it also to any employee, including common workers ${ }^{4}$. Just like in vast majority of countries, the restriction on competition in Latvia pertains to any employee regardless of their position, age or profession.

By disclosing information about company's strategy, cooperation partners, know-how and commercial secrets to employer's rivals and taking advantage of specific knowledge obtained at the former employer, the employee may cause great harm to his former employer.

Quite recently, the State Control of the Republic of Latvia audited the restriction on competition in the public sector and arrived at a conclusion which it announced publicly, namely, that in most cases such agreements were not signed to prevent competition to the employer's business in the public sector but rather to solve problems with employees unwilling to terminate employment relationships or - quite the contrary - to demonstrate particularly favourable attitude to some

1 Labour Law (20.06.2001). Available: https://likumi.lv/ta/en/en/id/26019-labour-law [last viewed 25.03.2021].

2 Grozijumi Darba likumā [Amendments to the Labour Law] (27.07.2017). Available: https://likumi.lv/ ta/id/292584-grozijumi-darba-likuma [last viewed 25.03.2021].

3 See, for example, Apple Exec Hired from IBM Ordered to Stop Work. Available: http://www.pcmag. com/article2/ 0,2817,2334163,00.asp [last viewed 22.03.2021].

4 Weiss, M., Schmidt, M. Labour Law and Industrial Relations in Germany. Wolters Kluwer, 2007, p. 147. 
employee. Respectively, the conclusion states that the employers from the public sector have not evaluated an objective need to enter in agreement on professional activity restrictions with a particular employee and there are no defined criteria which would be evaluated when determining the conditions of restrictions on professional activity of the employee, for example, the scope of remuneration to be paid, the period of restriction on professional activity. ${ }^{5}$ So, the State Control has come up with a proposal for the Cabinet of Ministers to elaborate a single regulation binding on all public sector employers operating in field of commerce and entering in agreements to restrict professional activity with their employers.

Henceforth, the article will analyse the goal, form and applicability preconditions and liability aspects and possibility for parties to withdraw from the agreed restriction on competition.

\section{Restriction on Competition After Termination of Employment Relationships - Notion, Goal and Applicability Preconditions}

\subsection{Notion of Restriction on Competition and Procedure of Entering into Agreement}

Article 84 of the Labour Law says that restriction on competition is an agreement between the employee and employer to restrict employee's professional activity after termination of employment relationships. Restriction on competition is based on employer's wish to protect themselves from activities of a former employee who may start competing with employer's business, besides the employee receives the agreed remuneration for entire period of restrictions. Article 84 of the Labour Law, which intends that the employer and employee can agree on restriction on professional activity, actually restricts the fundamental rights of a person specified in Article 106 of the Constitution of the Republic of Latvia - right to freely choose their employment and workplace according to their abilities and qualifications. ${ }^{6}$ Article 116 of the Constitution says the fundamental rights may be subject to restrictions in circumstances provided for by law if their goal is legitimate. Article 84 of the Labour Law allows both parties - employer and employee - to agree on restrictions on employee's professional activity after termination of employment relationships if the agreement meets the statutory preconditions.

Instrument of restriction on competition does not give a ready-to-use mechanism for the employer to safeguard from the competition as such, and instead it allows determining restrictions which are reasonably necessary to protect employer's legitimate interests. ${ }^{7}$

Such agreements can be entered into by any employer with any of his employees considered as holders of essential information, as well as employer in the public

5 Cik pamatoti no valsts lỉdzekḷiem tiek izmaksātas kompensācijas par profesionālās darbïbas ierobežojumu [How justified is compensation for restrictions on professional activity paid from state funds]? (23.03.2021). Available: https://www.lrvk.gov.lv/lv/covid-19/cik-pamatoti-no-valstslidzekliem-tiek-izmaksatas-kompensacijas-par-profesionalas-darbibas-ierobezojumu [last viewed 23.03.2021].

6 Latvijas Republikas Satversme [The Constitution of the Republic of Latvia] (15.02.1922). Available: https://likumi.lv/ta/en/en/id/57980-the-constitution-of-the-republic-of-latvia [last viewed 25.03.2021].

7 Bevitt, A., La Tanya, J. U.S. and E.U. Non-Competition Agreements Compared and Contrasted. Available: http://documents.jdsupra.com/d5bb690a-135c-4a53-b61e-0740d11d8002.pdf [last viewed 25.03.2021]. 
sector, which is State, the main task of which in business is to serve the public interests. $^{8}$

Paragraph 4 of Article 84 of the Labour Law states that an agreement to restrict competition must be executed in a written form and describe its type, scope, place, time and amount of compensation to be paid to employee. A requirement to execute agreement in a written form is set forth also in legislation of other countries. ${ }^{9}$ The Labour Law does not stipulate, when an agreement to restrict competition should be signed. Data shows that agreement to restrict competition after termination of employment relationships is signed as a separate agreement, following termination of the employment contract - the former employer in this case evaluates the level of knowledge, know-how and skills obtained and then decides how important it is to keep the employee away from immediate competitors by means of an agreement and what interest risks the employer might face.

However, the parties just as well may include the agreement on competition restriction in the employment contract (for example, immediately after entering into the employment contract or later when making amendments to it). It depends on the choice of both contractual parties and this possibility is also accepted in the case law. ${ }^{10}$

Of course, if the agreement on restriction on competition is signed at the moment of termination of employment relationships, the employees are often aware of the value of their new knowledge in such situation and therefore they can bargain for a larger compensation in exchange for compliance with the restriction on competition clause, as opposed to a situation where an agreement on competition restriction is signed with an employee who has just entered into employment relationship.

It must be noted that where the restriction on competition has been included in the employment contract, it is deemed to be a separate agreement subject to private law. ${ }^{11}$ The Supreme Court of Estonia, when examining the case of restriction on competition, has pointed out that agreement on competition restriction is not a part of the employment contract but rather a separate agreement subject to private law. ${ }^{12}$

Since the agreement on competition restriction largely restricts employee's fundamental rights, any country defines strict criteria in their legislation for such agreement to be valid. Paragraph 2 of Article 84 of the Labour Law stipulates that an agreement made between the employee and employer on the restriction on

8 Cik pamatoti ... [How justified ...]?

9 For example, a document drawn up in accordance with the first section of paragraph 74 of the Commercial Code of the Federal Republic of Germany must be handed over to the employee at the conclusion of the employment contract. In the event of a dispute, it is up to the employer to prove the conclusion of such an agreement. See the judgment of the Supreme Labour Court of the Federal Republic of Germany of 5 September 1995 in case No. 9 AZR 718/93.

10 Latvijas Republikas Augstākās tiesas Senāta Civillietu departamenta 2008. gada 26. novembra spriedums lietā Nr. SKC-424/2008 [Judgement of the Department of Civil Cases of the Senate of the Supreme Court of the Republic of Latvia of 26 November 2008 in case No. SKC-424/2008]. In: Latvijas Republikas Augstākās tiesas Senāta Civillietu departamenta spriedumi un lēmumi 2008 [Judgments and decisions of the Department of Civil Cases of the Senate of the Supreme Court of the Republic of Latvia 2008]. Rịga: Latvijas Tiesnešu mācību centrs, 2009, pp. 465-474.

11 Ibid.

12 Agreement on Non-Competition is not Part of Employment Contract. Available: http://www. labourlawnetwork.eu/ national_labour_law_latest_country_reports/national_court_rulings/court_ decisions/prm/64/v_detail/id_2927/category_10/index.html [last viewed 23.03.2021]. 
employee's professional activity after termination of employment relationships is permissible merely where the said agreement meets the following indications:

1) its goal is to protect the employer from employee's professional activity which may compete with the employer's business (given the protected information in possession of the employee);

2) term of restriction on competition is up to two years starting from termination of employment contract;

3) regarding the entire period of competition restriction, it obliges the employer to pay the employee adequate monthly compensation for compliance with the restrictions on competition for entire period of such restrictions.

Moreover, paragraph 2 of Article 84 of the Labour Law lays down one more imperative demand which must be fulfilled to make the agreement on competition restriction valid, i.e. - a restriction on competition may apply only to the area of activity performed by the employee during the employment relationships. ${ }^{13}$ The fundamental principle which must be observed when entering into an agreement on competition restriction is that there should be a reasonable balance between the legal interests of former employer and employee. Henceforth, the content of each precondition, understanding and application issues will be discussed in greater detail.

\subsection{Goal of the Restriction on Competition}

Clause 1 of paragraph 1 of Article 84 of the Labour Law explicitly states that the goal of restriction on competition is to protect the employer from employee's professional activity which may compete with the employer's business, given the protected information in possession of the employee.

Before amendments to the Labour Law in 2017 it contained no indication as to whether the restriction on competition applied also to employee's own business and prohibition to poach clients and employees of the former employer. Amendments to the Labour Law of 2017 supplemented Article 84 with paragraph 5, stating that "an agreement on the restriction on competition may apply to different types of restriction on competition, including permanent competitive economic activity of the employee, employment of the employee with another employer, not poaching of clients or employees of the former employer." Admittedly, before these amendments were adopted, the case law of Latvia already had an answer that the restriction on competition after termination of employment relationships was aimed at protecting employer's interests to safeguard against a new rival who can pursue professional activities after termination of their employment contract either in a capacity of an employee in a company from the same industry or founding his or her own company in the same industry. ${ }^{14}$ Thus, a notion professional activity

13 Latvijas Republikas Augstākās tiesas Senāta Civillietu departamenta 2009. gada 11.marta spriedums lietā Nr. SKC-99/2009 [Judgement of the Department of Civil Cases of the Senate of the Supreme Court of the Republic of Latvia of 11 March 2009 in case No. SKC-99/2009]. In: Tiesu prakse lietās par individuālajiem darba strīdiem [Case law in cases of individual labour disputes], 2010/2011. Available: http://at.gov.lv/files/uploads/files/docs/2011/individualie\%20darba\%20stridi.pdf [last viewed 19.02.2021].

14 Latvijas Republikas Augstākās tiesas Senāta Civillietu departamenta 2008. gada 26. novembra spriedums lietā. Nr. SKC-424/2008 [Judgement of the Department of Civil Cases of the Senate of the Supreme Court of the Republic of Latvia of 26 November 2008 in case No. SKC-424/2008]. In: Latvijas Republikas Augstākās tiesas Senāta Civillietu departamenta spriedumi un lēmumi 2008 [Judgments and decisions of the Department of Civil Cases of the Senate of the Supreme Court of the Republic of Latvia 2008], pp. 465-474. 
allows restricting former employee not only by prohibiting to work for a competing company (as an employee) but also running own business in a competing field, including providing services or professional consultations as self-employed person.

A restriction aimed at preventing family members of the former employee competing with the employer, as sometimes observed in practice, should be viewed critically. Not only such restriction is not binding on third parties, but such liability is not valid, since it does not comply with Article 1413 of the Civil Law, given that the former employee may not lawfully influence the will of other persons. At the same time, taking advantage of family members to bypass restrictions, which would be possible through a fiduciary deal, would be a violation of restriction on competition. A trustee in a fiduciary deal on his or her own behalf, however, serving the interests of the person authorising them, obtains or uses certain right because the authorising person either does not or cannot obtain or exercise this right ${ }^{15}$. Therefore, when actual violation of restriction on competition by agency of a trustee is identified, there is a ground to believe the employee has violated the agreement.

A novelty in amendments of 2017 is that they expressis verbis stipulate that restriction on competition may apply also to the type of competition restriction such as prohibition of poaching a customer or a former employee of the employer. A prohibition to poach the customers of the former employee is not a topic widely elaborated upon in the legal doctrine of Latvia, however, foreign doctrine attributes non-poaching obligation only to active employer's customers during the period of competition restriction, but not to former customers. ${ }^{16}$ For example, in Denmark it has been specified that non-poaching obligation applies to customers who have received any service from the employee in 18 months' period before the employee terminated the employment relationship with the employer. ${ }^{17}$ Meanwhile, nonpoaching obligation concerning employees prohibit a former employee to make any offerings, suggestions or convince the employees of former employer to leave their current workplace. ${ }^{18}$ In the context of poaching, it is sometimes difficult to understand whether the former employee has been "poached" or it was a voluntary act and decision of a customer or employee respectively. As the legal literature reasonably states, one must consider that the burden of proof regarding the violation of competition restriction rests upon the employer, and it means that "employer will have an obligation to prove that employer's customers and employees were poached, and it was not a voluntary action or initiative of customers and employees. The Labour Law is not in a position to restrict the wish of customers and employees to cooperate with a preferred company, nevertheless the Labour Law restricts employee's poaching efforts." 19

Germany, too, in its case has concluded law that an employer has justified business interests if non-compete obligation serves either for protection of business secret or prevents the employee who no longer has employment relationships with the employer to access the customers or suppliers, or prevents or restricts him from

15 Balodis, K. Ievads civiltiesībās [Introduction to Civil Law]. Rīga: Zvaigzne ABC, 2007, pp. 248-249.

16 Campbell, D. Post-Employment Covenants in Employment Relationships. Alphen aan den Rijn: Kluwer Law International, 2014, p. 293.

17 Lagesse, P., Norrbom, M. Restrictive Covenants in Employment Contracts and Other Mechanisms for Protection of Corporate Confidential Information. Alphen aan den Rijn: Kluwer Law International, 2006, p. 39.

18 Holland, J. A., Burnett, S. A. Employment Law. New York: Oxford University Press, 2008, p. 211.

19 Darba likums ar komentāriem [Labour Law with Comments]. Rìga: Latvijas Brīvo arodbiedrību savienība, 2020, p. 227. 
using special knowledge or personal contacts. A simple interest of the employer in restricting the competition is not sufficient to argue in favour of entering into such agreement. $^{20}$

\subsection{Due Date of the Restriction on Competition}

Clause 2 of paragraph 1 of Article 84 of the Labour Law states that a term of the restriction on competition may not exceed two years starting from the day of termination of legal employment relationships. As the existing practice demonstrates, the parties in Latvia usually agree on one- or two-years' term for restriction on competition.

Also, laws and regulations of several Member States of the European Union, similarly to the Labour Law of Latvia, lay down two-years' term for restriction on competition (for example, Lithuania ${ }^{21}$, Germany ${ }^{22}$, Hungary ${ }^{23}$, Slovenia ${ }^{24}$ ). The maximum term in Estonia ${ }^{25}$ and Belgium ${ }^{26}$ is 1 year, while in Ireland and Finland ${ }^{27}$ the term of the restriction on competition may not exceed 6 months.

The Labour Law sets 2 years as the maximum term for all employees, nevertheless, several countries have chosen to differentiate the longest competition restriction term depending on the employee's position. For example, qualified specialists in Spain may be subject to the maximum restriction on competition of 2 years, while the term of restriction on competition of an unqualified worker who had access to the business secret of former employer may not exceed 6 months. ${ }^{28}$ In Romania, this period is 2 years for leading positions and 6 months for other workers. Meanwhile, the maximum term of general restriction on competition is 2 years, but in exceptional cases, if the employee's job duties are related to highly sensitive information concerning competition area or relationships of trust, the term of such restrictions may be even 3 years. ${ }^{29}$ Italy stands out among other countries with a long permissible term of restriction on competition, where employees who used to be in top positions can be subject to even 5 years of non-competition term,

20 Judgment of the Federal Supreme Labour Court of the Federal Republic of Germany of 1 August 1995 in case No. 9 AZR 884/93.

21 Lietuvos Respublikos darbo kodeksas [Labour Code of the Republic of Lithuania], Art. 38. Available: https://e-seimas.lrs.lt/ [last viewed 31.03.2021].

22 Weiss, M., Schmidt, M. Labour Law ..., p. 147.

23 On the Labour Code of Hungary. Available: http://www.ilo.org/wcmsp5/groups/public/---ed_protect/--protrav/---ilo_aids/documents/legaldocument/wcms_186075.pdf [last viewed 31.03.2021].

24 Novak, J. Prohibition of Competition and Non-Competition Clauses in Labour Contracts. Slovenia. XIV th Meeting of European Labour Court Judges 4 September 2006. Available: https://www.ilo.org/ wcmsp5/groups/public/@ed_dialogue/@dialogue/documents/meetingdocument/wcms_159970.pdf [last viewed 31.03.2021].

25 Employment Contracts Act, Art. 24. Available: https://www.riigiteataja.ee/en/eli/520062016003/ consolide [last viewed 31.03.2021].

26 Storck, C. Non-Competition Clauses in Labour Contracts. Belgium. XIV ${ }^{\text {th }}$ Meeting of European Labour Court Judges, 4 September 2006. Available: https://www.ilo.org/wcmsp5/groups/public/--ed_dialogue/ dialogue/documents/meeting document/wcms_159959.pdf [last viewed 31.10.2020].

27 Employment Contracts Act. Sect. 5. Available: https://finlex.fi/en/laki/kaannokset/2001/en20010055. pdf [last viewed 31.03.2021].

28 Valverde, A. M., Salmerón, B. R., Luque, L., García, F. F. Non-Competition Clauses in Labour Contracts. XIV $^{\text {th }}$ Meeting of European Labour Court Judges 4 September 2006. Available: http://www.ilo.org/ wcmsp5/groups/public/---ed_dialogue/---dialogue/documents/meetingdocument/ wcms_159971. pdf [last viewed 19.03.2021].

29 Gomes Vieira, J. M., de Oliveira Carvalho, C. Labour Law in Portugal. Kluwer Law International, 2011, p. 110. Portuguese Labour code. Available: http://www.cite.gov.pt/pt/legis/CodTrab_L1_004. html\#L004S9 [last viewed 19.03.2021] 
while it may not exceed 3 years for other employees. ${ }^{30}$ Austria has an interesting approach to competition restriction. Professional activity cannot be restricted for more than one year, nevertheless, the employer is entitled to enter into such agreement with a person whose monthly income exceeds the defined threshold which is determined by the Austrian Federal Ministry of Labour, Social Affairs, Health and Consumer Protection on annual basis. ${ }^{31}$

Approach to maximum term chosen by Latvia is generally considered reasonable because, on the one hand, it can provide sufficient protection of employer's interests (in contrary to a rather short term of 6 months) and, on the other hand, if an employee were subject to a term exceeding 2 years and he would not work in his or her speciality, he could face a risk of losing the qualification entailing loss of competitiveness in the labour market in future. Judgements of several countries' courts imposing life-long restrictions on competition must be marked as unique. ${ }^{32}$

Upon expiry of the term under the agreement, the employee can freely use their professional skills also against the former employer by working at a competing economic operator or launching one's own business in the same field.

\subsection{Adequate Compensation for Restriction on Competition}

Payment of compensation for the entire period of restriction on competition is mandatory to keep the restriction on competition valid. The primary goal of compensation is to compensate for employee's restricted career development opportunities and providing him or her with means of subsistence. ${ }^{33}$

The Labour Law of Latvia does not provide fixed criteria for the amount of remuneration (compensation) to be paid to employees for restriction of competition after termination of employment relationships. Clause 3 of paragraph 1 of Article 84 of the Labour Law states that an agreement between the employee and employer on restriction on employee's professional activity is permissible only where the mentioned agreement obliges the employer to pay adequate compensation to the employee for compliance with the restriction on competition for the entire period of such restriction. "Adequate compensation" is an ambiguous notion or general clause in law, which must be given content in each particular case.

The amount of adequate compensation varies from case to case and no rigid boundaries can be drawn to judge the adequacy of the compensation. It can be affected by term of the restriction on competition, or the position assumed by employee, field of activity, market situation and similar factors. ${ }^{34}$

Since the Labour Law does not stipulate the amount of minimum compensation to be paid out, the lack of such regulation has been frequently criticised. Some authors have tried to define the notion of "adequate compensation", for example,

30 Mammone, G. Non-Competition Clauses in Labour Contracts. Italy. XIV ${ }^{\text {th }}$ Meeting of European Labour Court Judges, 4 September 2006. Available: http://www.ilo.org/wcmsp5/groups/public/--ed_dialogue/--dialogue/documents/meeting document/wcms_159966.pdf [last viewed 19.03.2021].

31 Kuras, G. Non-Competition Clauses in Labour Contracts. Austria. XIV ${ }^{\text {th }}$ Meeting of European Labour Court Judges, 4 September 2006. Available: https://www.ilo.org/wcmsp5/groups/public/--ed_dialogue/---dialogue/documents/meeting document/wcms_159958.pdf [last viewed 19.03.2021].

32 Note. Laws in such countries do not stipulate the maximum term of restriction on competition and such admissibility was examined by courts. See Selwyn, N. M. Selwyn's Law of Employment. $14^{\text {th }}$ edition. Oxford: Oxford University Press, 2006, p. 484.

33 Rācenājs, K. Ierobežojumi pēc darba tiesisko attiecību izbeigšanās [Restrictions after termination of employment]. Jurista Vārds, No. 39(492), 25.09.2007.

34 Darba likums ar komentāriem [Labour Law with comments], p. 225. 
a specialist in the labour law and lawyer I. Gailums pointed out that it would be fair if monthly compensation reached $60-90 \%$ of employee's average salary. ${ }^{35}$

Unlike the flexible regulation in Latvia, which gives the parties a rather extensive private autonomy in setting the compensation amount, many countries have laid down certain limits of minimum compensation in their laws and regulations. For example, compensation in France must be at least $30 \%$ of previous salary, in Lithuania - $40 \%$ of employee's average salary ${ }^{36}$, compensation in Romania must be at least $1 / 4$ of current salary, and in Hungary - at least 1/3 of employee' previous salary $^{37}$. Compensation in Germany ${ }^{38}$, Belgium ${ }^{39}$ and Denmark ${ }^{40}$ must equal at least one half of the current salary.

At the first glance, it may seem that the Labour Law of Latvia would also benefit from determining the minimum threshold of such compensation, but at the same time a notion "adequate payment" stated in the Labour Law gives parties some flexibility and allows choosing a mutually advantageous compensation. For example, if the restriction is rather narrow and limits employee's possibility to work for one particular competitor of the former employer, the amount of compensation could be lower than $1 / 3$ of current salary, like the case often is in other countries.

The compensation stipulated in the agreement can be formulated as certain amount or expressed as percentage of current employee's salary, payment for work, average salary etc. And the scope of monthly compensations might as well differ, for instance, one could agree that 400 euro are paid monthly for the first half-year and 300 euro are paid for the rest of period. If the agreement to restrict competition is made upon establishing the employment relationship or during it, it is preferable to express compensation in percentage from the salary rather than as a fixed sum which could be far from adequate compensation concept on the moment of termination the employment relationships considering a possible inflation.

Laws and regulations of many other countries show that the compensation must be reasonable or adequate. Since a restriction on competition does not translate to prohibition on employee to work but rather a restriction on certain field of activity, the compensation must not replace all earnings a person received so far. The Labour Law does not specify a list of criteria to be used for identifying adequacy - it must be considered individually in each case.

As already mentioned, the parties may integrate an agreement to restrict competition, including the scope of the remuneration to be paid, already in the employment contract. However, it may take long before the parties terminate the employment relationships and there is a possibility that the compensation agreed

35 Gailums, I. Darba likums. Komentāri. Tiesu prakse [Labour Law. Commentaries. Case Law]. $2^{\text {nd }}$ Book. Rīga: Gailuma juridiskā biznesa biroja izdevniecība, 2003, p. 154.

36 Lietuvos Respublikos darbo kodeksas [Labour Code of the Republic of Lithuania], Art. 38(3). Available: https://e-seimas.lrs.lt/ [last viewed 12.03.2021].

37 On the Labour Code of Hungary. Available: http://www.ilo.org/wcmsp5/groups/public/---ed_ protect/---protrav/---ilo_aids/documents/legaldocument/wcms186075.pdf [last viewed 12.03.2021].

38 Judgment of the Federal Supreme Labour Court of the Federal Republic of Germany of 22 October 2008 in case No. 10 AZR 360/08; Spinner, G. Kommentar zum Paragraph 611a des Bürgerliches Gesetzbuches. In: Henssler, M., Krüger, W. (Red.). Münchener Kommentar zum Bürgerlichen Gesetzbuch. Band 5. Schuldrecht. Besonderer Teil II. $\$ \$$ 535-630h. 8. Aufl. München: C. H. Beck, 2020, § 611a, Rn. 1148.

39 Clifford Chance. Employment and Benefits in the European Union. London: Clifford Chance LLP, 2007, p. 12.

40 International Business Publications. Denmark Investment and Business Guide. Volume 1. Strategic and Practical Information. Washington: International Business Publications. USA, 2015, p. 130. 
is no longer adequate for the updated market salary at the moment of employment termination. Thus, in order to assess rationality and fairness of compensation, one should look at the situation when the restrictions are actually imposed rather than once agreed on in the contract.

The current case law does not permit to draw general objective conclusions about the amounts of adequate compensation. It can be concluded from the case law that the range of compensations in Latvia is rather impressive, at the same time, the type and scope of restrictions stated in these agreements are essentially different ${ }^{41}$. For example, laws and regulations of Lithuania did not have a comprehensive rules on restriction on competition and hence the amount of compensation to be paid before the new (applicable) Labour Code was adopted in 2017; nevertheless, in 2013, the Supreme Court of Lithuania, examining a case, also assessed the adequacy of compensation in the context of scope of restrictions and decided that the compensation amounting to $9 \%$ of the employee's previous salary, given the restrictions imposed on this employee, was too low and therefore did not meet the principle of honesty and fairness. ${ }^{42}$

There is an opinion found in the legal literature that if a minute compensation is offered for restriction on competition, i.e., $10 \%$ of average salary, the employee will not have resources to achieve that, and court declares such agreement as invalid due to unfair conditions. ${ }^{43}$ When deciding on the amount of adequate payment, each case must be viewed individually. The court should look both on period bound for restriction on compensation and position assumed by the employee, employee's education and previous experience, field of activity and general situation in the labour market.

Before adoption of the amendments in 2017, the Labour Law did not govern the moment of payment of the compensation, i.e., it merely stipulated that compensation shall be paid monthly and it shall be paid for entire period of restriction. Back then, the Senate of the Supreme Court, when examining the procedure of compensation for restriction on competition, had ruled that such compensation can be paid out both after termination of the employment relationships and in advance, before termination of employment relationships, and this choice should be agreed by the parties alone. ${ }^{44}$ Amendments of 2017 specified clause 3 of paragraph 1 of Article 84 stated that the compensation shall be paid

${ }_{41}$ For example, in the judgment of Sigulda court of 14 February 2007 in case No. C35045806 (not published) the amount of compensation is set at LVL 40; In the judgment of the Riga City Zemgale Suburb Court of 6 March 2008 in the case No. C31127906 (not published) the amount of remuneration is set at LVL 250; In the judgment of the Riga District Court of 18 December 2009 in case No. C33287709 (not published) the amount was determined LVL 580.13 for the first three months, then in the amount of LVL 348.08 for 9 months and in the amount of LVL 116.03 for the last twelve months. For example, in a case, the Kurzeme Regional Court has acknowledged that the compensation paid to an employee of LVL 25 for a restriction of competition and later LVL 70 per month is not appropriate and fair. (See Judgment of 9 January 2008 of the Department of Civil Cases of the Senate of the Supreme Court of the Republic of Latvia in case No. SKC-6.)

42 Viešūnaite, V. How to Conclude a Valid Lithuanian Non-Competition Agreement. Available: http://triniti. ee/en/archives/4420 [last viewed 12.03.2021].

43 Gailums, I. Darba likums [Labour Law], p. 155.

44 Latvijas Republikas Augstākās tiesas Senāta Civillietu departamenta 2008. gada 26. novembra spriedums lietā Nr. SKC-424/2008 [Judgement of the Department of Civil Cases of the Senate of the Supreme Court of the Republic of Latvia of 26 November 2008 in case No. SKC-424/2008]. In: Latvijas Republikas Augstākās tiesas Senāta Civillietu departamenta spriedumi un lēmumi 2008 [Judgments and decisions of the Department of Civil Cases of the Senate of the Supreme Court of the Republic of Latvia 2008], pp. 465-474. 
monthly "following the termination of employment relationships", meaning that the law prohibited paying the compensation in advance, during the employment relationships.

Other countries do not have a uniform regulation of the moment of the compensation payment, for example, a compensation for compliance with noncompete obligation in Italy can be paid also during the period of employment relationships, ${ }^{45}$ nevertheless, in majority of countries, the compensation is paid after termination of the employment relationships ${ }^{46}$, for example, in Germany it is stated that such compensation is to be paid every month for the period of restrictions. ${ }^{47}$

Even though parties enjoy a rather extensive freedom of choice when it comes to the content of agreement to restrict competition, the payment of compensation should not be bound to certain circumstances, stating that the compensation is paid only where the former employee is proved to be working for employer's rival and in similar events. Here, Articles 1551 and 1558 of the Civil Law (hereinafter referred to as "CL") on suspensive condition will not apply. ${ }^{48}$

Issue on the amount of compensation in Latvian case law is rather poorly debated, however, the Supreme Court in its judgement of 2007 analysed some possible criteria of adequate compensations. The Supreme Court pointed out linking the amount of agreed compensation to employee's education, skills and possibilities is not reasonable without identifying the ways the education and skills were a precondition to assuming given position. It does not matter if the employee, having education and set of skills, could do other kind of job too, when assessing compliance of compensation for the restriction on competition with requirements put forth in said legal provision, if the employee chose to work in that position and consented to the compensation under agreement. Given the circumstances established by the district court, i.e., that after ending the employment relationships with the employer for whom he worked as a car seller, the employee started working for other employees with job duties also related to car selling, the court based on unsubstantiated criteria - compensation for restriction on competition - for deciding this issue. At the same time, the proposed criteria regarding the salary offered by the rival contradicts the statutory goal of competition restriction - to protect employer from professional activity of employee which may compete with employer's business (clause 1 of paragraph 1 of the Labour Law) - and therefore it is not applicable to interpretation of clause 3 of paragraph 1 of Article 84. Thus, by proposing wrong criteria for deciding an issue on whether the remuneration under agreement is to be admitted as fair, the court misinterpreted clause 3 of paragraph 1 of Article 84 of the Labour Law. ${ }^{49}$

In the context of compensation amount a judgement of 2019 by the Civil Court Panel of Riga Regional Court draws attention. ${ }^{50}$ The merits of this case were that

45 Mammone, G. Non-Competition Clauses ...

46 Storck, C. Non-Competition Clauses ...

47 Spinner, G. Kommentar zum Paragraph 611a des Bürgerliches Gesetzbuches. , \$ 611a, Rn. 1148.

48 See, e.g., the judgment of the Riga District Court of 17 December 2013 in case No. C33334313 (not published and has not entered into force due to the concluded settlement).

49 Latvijas Republikas Augstākās tiesas Civillietu departamenta 2007. gada 29. augusta spriedums lietā Nr. SKC-560/2007 [Judgement of the Department of Civil Cases of the Senate of the Supreme Court of the Republic of Latvia of 29 August 2007 in case No. SKC-560/2007] (not published).

50 Rīgas apgabaltiesas Civillietu kolēǵijas 2019. gada 15. augusta spriedums lietā Nr. C32179317. [Judgment of the Chamber of Civil Cases of the Riga Regional Court of 15 April 2019 in case No. C32179317]. Available: https://manas.tiesas.lv/ [last viewed 01.04.2021]. 
the parties entered an employment contract in 2012, whereby the employer hired the employee as a car technician with a stipulated salary of 284.57 euro per month, and this amount was increased to 375 euro per month with later amendments. By entering into the employment contract, the parties had agreed that in order to prevent competing with the employer's business, the employee was not entitled to pursue professional activity or work for another employer in a way that created competition to former employer's business in the territory of Latvia, Lithuania and Estonia for two years after termination of employment relationships. The employer agreed to initially pay for such restriction on competition a monthly compensation of 14.23 euro, increasing that amount later to 15 euro monthly. The employment contract stipulated the penalty for violation the non-competing obligation equals to 24 monthly salaries. ${ }^{51}$ The employer found out that the employee had started employment relationships with another employer specialising in car maintenance (thus creating a competition to the company of the former employer) within two years after termination of employment relationship, therefore, the first filed a case in the court against the former employee demanding the return of all monthly compensations paid plus a contractual penalty, as stated in the employment contract. The initial amount of the contractual penalty calculated by the employer was 9,000 euro, however, it was recalculated in compliance with Articles 1 and 1717 of the Civil Law, and an action was brought to the court demanding payment of contractual penalty of 3000 euro. The employee, in his turn, responded with a counter-action, requesting that the relevant clauses in the employment contract are declared invalid. When examining this dispute in a court of second instance, the court rejected employee's argument that monthly compensation of 15 euro for compliance with non-competition obligation was not adequate. The Regional Court stated:

claimant's objections were declared on the moment he was demanded to return the compensation and pay contractual penalty, given that the employee had violated the restriction on competition. [..] During validity period of the employment contract and also on the moment of signing the amendments, the employee did not raise any objections regarding the restriction on competition or amount of compensation under that agreement. Thereby the employee expressed his consent to the restriction on compensation, compensation payment and its amount as offered by the employer.

Concerning the amount of the contractual penalty, the court concluded that it was not adequate and decided to recover a contractual penalty of 750 euro from the former employee. ${ }^{52}$

\subsection{Notion of the Field of Activity}

As noted above, paragraph 2 of Article 84 of the Labour Law states that competition restriction may apply only to the field of activity whereof the employee was hired during the employment relationships. The employer is not entitled to impose overly wide restriction on competition, it must be commensurable and serve the interests of both parties. ${ }^{53}$

51 Rīgas apgabaltiesas Civillietu kolẹǵijas 2019. gada 15. augusta spriedums lietā Nr. C32179317. [Judgment of the Chamber of Civil Cases of the Riga Regional Court of 15 April 2019 in case No. C32179317], p. 1. Available: https://manas.tiesas.lv/ [last viewed 01.04.2021].

52 Ibid., pp. 4-5.

53 Miller, R. L., Jentz, G. A. Fundamentals of Business Law: Excerpted Cases. $2^{\text {nd }}$ edition. Mason: SouthWestern Cengage Learning, 2009, p. 202. 
The Senate of the Supreme Court has admitted that specifying the fields of activity subject to restriction in the agreement is not a mandatory prerequisite for its validity because the mentioned legal provision does not demand the competing field or industry subject to restriction where the former employee is not entitled to work after termination of employment relationships be included in the agreement since it is already provided for by the law..$^{54}$ In this way, even if the agreement to restrict competition fails to list the fields of activity where the employee may not operate after termination of employment relationships in greater detail, paragraph 2 of Article 84 of the Labour Law states that the restriction of professional activity of the employee applies merely to the field where employer operates, besides taking into account the position and job duties of the employee. For example, if an agreement on competition restrictions was signed by a food technologist who previously worked in the meat processing sector, there would be no grounds to restrict his right to work in the confectionery sector.

The Supreme Court in its judgement of 9 January 2008 in case No. SKC-6 shared the conclusion of lower instance courts that a restriction on competition imposed on a secretary, who has worked for a car sales company which generally prohibits working in any company operating in the field of car or spare part and accessory sales, maintenance, repair, rent or lease, being an employee of such company and providing professional consultations to a company or entrepreneur related to any of these lines of direction, to be incommensurate and unreasonable. ${ }^{55}$

\subsection{Type and Scope of Restriction on Competition}

In compliance with paragraph 4 of Article 84 of the Labour Law, type and amount of compensation for competition formulated in a written form is a prerequisite of agreement's validity.

Sometimes notions type and scope of restriction have caused confusion because the practice has seen cases where parties refer to an argument that contract does not contain one of these elements - either type or scope, - and have tried to insist on invalidity of such agreement. For example, the Supreme Court in its judgement, arguing against the appellant who insisted that there were no type and scope of restriction on competition provided in the agreement, gave definitions to notions "type" and "scope", explaining that in context of this case, type of restriction is not to enter in employment relationships with other light vehicle sales companies, and scope - at least not to work as the seller in other light and off-road vehicle sales companies. ${ }^{56}$

${ }^{54}$ Latvijas Republikas Augstākās tiesas Senāta Civillietu departamenta 2008. gada 26. novembra spriedums lietā Nr. SKC-424/2008 [Judgement of the Department of Civil Cases of the Senate of the Supreme Court of the Republic of Latvia of 26 November 2008 in case No. SKC-424/2008]. In: Latvijas Republikas Augstākās tiesas Senāta Civillietu departamenta spriedumi un lēmumi 2008 [Judgments and decisions of the Department of Civil Cases of the Senate of the Supreme Court of the Republic of Latvia 2008], pp. 465-474.

55 Latvijas Republikas Augstākās tiesas Senāta 2008. gada 9. janvāra spriedums lietā Nr. SKC-6/2008 [Judgement of 9 January 2008 of the Department of Civil Cases of the Senate of the Supreme Court of the Republic of Latvia in case No. SKC-6/2008] (not published).

56 Latvijas Republikas Augstākās tiesas Senāta Civillietu departamenta 2008. gada 26. novembra spriedums lietā Nr. SKC-424/2008 [Judgement of the Department of Civil Cases of the Senate of the Supreme Court of the Republic of Latvia of 26 November 2008 in case No. SKC-424/2008]. In: Latvijas Republikas Augstākās tiesas Senāta Civillietu departamenta spriedumi un lēmumi 2008 [Judgments and decisions of the Department of Civil Cases of the Senate of the Supreme Court of the Republic of Latvia 2008], pp. 465-474. 
Amendments to the Labour Law of 2017, adding paragraph 5 to Article 84, brings some clarity on what the types of restriction on competition are. Paragraph 5 of Article 84 of the Labour Law lists the main types of restrictions on competition, i.e., prohibition to work for competitors of former employer, prohibition to launch own business which competes with former employer, as well as prohibition to poach customers and employees of the former employer, however, this list of types of restrictions is not exhaustive.

\subsection{Understanding the Place of Restriction on Competition}

Similarly to the field of activity, type and scope of the restriction on competition, also the place of restriction on competition (territorial scale) is directly associated with employer's economic activity. In order to evaluate validity of the place of restriction on competition, each case must be examined separately, i.e., what is the territory where employer conducts his business and employs the staff.

The territory subject to restriction can be a village, town or city, county, state or even a group of countries. For example, in international companies which operate in a number of countries, agreement often imposes restriction on competition both in Latvia and other countries where the company operates, and such practice is supportable. When defining the territory, one must stick to reasonable criteria, for example, it would be fair to impose a territorial restriction only where the former employer already runs business in that territory or clearly intends to launch business there shortly; however, there are no grounds for prohibition to enter into employment relationships in countries where the employer does not plan to operate.

Latvian case law in one particular case has also examined commensurability of territorial restriction and the court ruled in that case that a restriction is commensurable for Latvia, whereas incommensurable for Lithuania and Estonia, and therefore the last ones were declared invalid. ${ }^{57}$

\section{Consequences from Restriction on Competition Failing to Meet the Statutory Preconditions}

Paragraph 3 of Article 84 of the Labour Law states that an agreement to restrict competition is not valid to an extent it is deemed to be an unfair restriction of future professional activity of the employee given the type, scope, place and time of competition restriction and compensation to be paid out to the employee.

The Supreme Court has decided that "said legal provision links declaring the agreement invalid to a limitation - to an extent the defined type, scope, place and time and also compensation amount are found unfair." ${ }^{58}$ Therefore, for instance, if an agreement specifies excessively large territory subject to the restriction on competition it does not mean that agreement on competition restriction will lose force entirely, but rather just that particular provision which is considered to be unfair restriction of employee's future professional activity. The Supreme Court in its judgment demonstrated the so-called "blue pencil rule"59, namely, that paragraph

57 Latvijas Republikas Augstākās tiesas Senāta 2007. gada 29. augusta spriedums lietā Nr. SKC-560/2007 [Judgement of the Department of Civil Cases of the Senate of the Supreme Court of the Republic of Latvia of 29 August 2007 in case No. SKC-560/2007] (not published).

58 Ibid.

59 More about "blue pencil rule" see Pivateau, G. T. Putting the Blue Pencil down: An Argument for Specificity in Noncompete Agreements. Nebraska Law Review, Vol. 84, No. 3, 2008. Available: http:// papers.ssrn.com/sol3/papers.cfm?abstract_id=1007599 [last viewed 12.03.2021]. 
4 of Article 84 of the Labour Law entitles the court to declare an agreement to restrict competition after termination of employment relationships invalid only in section which is deemed to be an unfair restriction of future professional activity of the employee. In this case it was concluded that conditions restricting the employee's possibility to work in Lithuania and Estonia were incommensurate, yet they were adequate for Latvia, and therefore there were no grounds for invalidating the entire agreement. The court retains provisions which in given circumstances are not considered an unfair restriction of future professional development of the employee and declares provisions which are unfair in given circumstances invalid, therefore as if "rewriting" the very agreement. ${ }^{60}$

The so-called "blue pencil rule" entitles the courts either to (1) cross out provisions from the agreement which are declared by the court as unfair restrictions of employee's further professional development, leaving in force only those with statutory compliance, or (2) actually amend the agreement entered into by the employer and employee and include new provisions serving the parties' interests. ${ }^{61}$ National regulations of each country concerning application of the blue pencil rule differ in that majority of countries have given the court a right to cross out unfair conditions and leave others intact.

For example, German courts apply the blue pencil rule and where the conditions of agreement are too wide and ambiguous or where employee's rights are excessively restricted, they "rewrite" conditions of agreement signed by the parties, or to be more specific - exclude provisions which are non-compliant in court's view ${ }^{62}$. Court rights in the U.S. State of Texas in terms of editing the competition restrictions are even ampler, i.e., not only the court may delete clauses, but also supplement the agreement with new ones, bringing parties' interests to balance. ${ }^{63}$ Meanwhile, Italy employs a contrary principle which does not entitle a court to modify an agreement signed between employer and employee. Italian courts, referring to the private nature of such agreement, have decided that a court is not in a position to amend or change the provisions contained therein. The court may only evaluate whether the mentioned agreement complies with legal provisions and is valid, or alternatively restricts employee's rights and therefore is to be declared invalid. ${ }^{64}$

Even though the Supreme Court of the Republic of Latvia has recognised admissibility of the blue pencil rule in its practice, the Labour Law fails to provide a clear answer about the scope of applicability of that rule. The author believes that Latvian legal system should accept court's authority to declare invalid and delete conditions of an agreement which are incommensurable and too restrictive on one party, however, the court should not be allowed to actually amend the agreement

60 Tiesu prakse lietās par individuālajiem darba strīdiem [Case law on individual labour disputes].

${ }^{61}$ Pivateau, G. T. Putting ...

62 Eylert, M. Non-Competition Clauses in Labour Contracts. Germany XIVth Meeting of European Labour Court Judges 4 September 2006. Available: http://www.ilo.org/wcmsp5/groups/public/--ed_dialogue/---dialogue/documents/meeting document/wcms_159962.pdf [last viewed 12.03.2021]. See also: Spinner, G. Kommentar zum Paragraph 611a des Bürgerliches Gesetzbuches., § 611a, Rn. 965; Judgment of the Federal Supreme Court of the Federal Republic of Germany of 18 February 2016 in case No. III ZR 126/15, para. 37.

63 United States District Court, S. D. Texas, Houston Division. January 12, 2009. TransPerfect Translations, Inc. v. Leslie. Available: https://www.courtlistener.com/opinion/1902491/transperfecttranslations-inc-v-leslie/ [last viewed 02.04.2021]; Osis, G. Konkurences ierobežojums pēc darba tiesisko attiecību izbeigšanās [Restriction of competition after termination of employment relations]. Rìga: Latvijas Universitāte, 2019, pp. 22-23.

64 Mammone, G. Non-Competition Clauses ... 
entered into by and between the employer and employee and add new provisions. The court already performs its duty by declaring the incommensurate conditions of the agreement invalid - thus preventing conditions which deteriorate the legal situation of the employee or employer.

By applying paragraph 3 of Article 84 of the Labour Law, the court evaluates and gives content to notion "unfair restriction of professional activity". The court may not translate it wider, and it must scrutinise each criterion separately, and if it declares one of the agreement's provisions to be an unfair restriction of further professional development of the employee, the agreement to restrict competition must be declared invalid in relevant points. ${ }^{65}$

If the parties failed to comply with provisions of paragraph 4 of Article 84, namely, that the agreement on restriction on competition must be prepared in a written form, and the parties were found to agree on competition restrictions verbally and then violate these provisions (i.e. employer pays compensation, besides the employee complies with the agreed restriction on competition), then failure to comply with the written form should not automatically render the competition restrictions invalid (see Article 1488 of CL) ${ }^{66}$.

\section{Responsibility for Violation of the Restriction on Competition and Reinforcement of Liability}

Sometimes in practice there are situations where one of parties does not want to fulfil their liabilities after signing an agreement to restrict competition, for example, a former employer no longer pays the agreed monthly compensation, or alternatively, the second most frequent case, when an employee, in contrary to the agreement, does not comply with the type or scope of competition restrictions and enters new legal relationships.

If the employer has violated conditions of the agreement, i.e., does not pay a compensation - it does not entitle the employee to violate provisions of the agreement by unilaterally withdrawing from it, unless such right is explicitly stipulated. In this case, Article 1588 of CL applies, and it states that one party may not withdraw from the agreement without a consent of other party even if the latter fails to perform it and because that party does not perform it. In this situation, the employee must put Article 1589 of CL into action, i.e., the employee is entitled to demand performance of agreement, that is to say - payment of compensation. The employee is also entitled to request recovery of interest set by law on the basis of Article 1765 of CL. The employee is likewise entitled to request cancelling of entire agreement on the basis of Article 1663 of CL.

On the other hand, if the employee has violated non-competition obligations, the employer has several means of civil protection to protect their rights, i.e.,

1) a right to oblige to perform the agreement (i.e., not to engage in competing activities, Article 1589 of CL);

2) to recover loss from employee (Article 1779 of $\mathrm{CL}$ );

3) to recover the agreed contractual penalty (Article 1716 of $\mathrm{CL}$ );

4) reclaim the competition compensation paid out for the period when the employee violated the agreement (Article 2389 of CL);

65 Tiesu prakse lietās par individuālajiem darba strīdiem [Case law on individual labour disputes].

${ }^{66}$ Civillikums [The Civil Law] (28.01.1937). Available: https://likumi.lv/ta/en/en/id/225418-the-civillaw [last viewed 11.03.2021]. 
5) to recover interest set by law (Article 1765 of CL);

6) to request annulment of the agreement (Article 1663 of CL);

7) to refer to default on obligations as a reason for withholding further payments to the employee due to violation of prohibition to compete (Article 1591).

The first of mechanisms - the right to oblige the former employee to perform what was agreed may be tardy and inefficient, for example, the employer might learn rather late that the employee violates the provisions of the agreement and given the long duration of examination of cases in courts, it may result in lost basis of the claim and enforcement of the claim may turn out impossible (especially if restriction on competition is short-term).

Regarding the compensation for damage, it might be difficult to prove the loss, as the employee must prove the scope of loss which is hard to do in real life.

The most efficient mechanism for protecting the interests of a former employer is reinforcement of liabilities with contractual penalty. The employee, for the purpose of protecting his legal interests, can find it useful to include contractual penalty in agreement to restrict competition - then it would suffice to merely establish the fact of violation on employee's part to create a basis for demanding the employee to pay the contractual penalty according to Article 1716 of CL as for full default on obligations.

Also, legal doctrine of Germany has admitted that it is often not enough to request refraining from an activity and claim for damages to keep the employee from violating the non-compete obligation (because due to its complicated structure they may lack effectiveness), the obligation of employee to comply with competition restriction can be reinforced with a contractual penalty (integrating it in general transaction provisions, too). ${ }^{67}$

The case law regarding the reinforcement of liability in area of restrictions on competition has changed over the years. Until 2008, an opinion existed both in the literature and case law that the Labour Law does not offer contractual penalty as the reinforcement of liability, and Article 6 of the Labour Law invalidates provisions of an employment contract which, in contrary to the legislative acts, deteriorate employee's situation. ${ }^{68}$ The Supreme Court with its judgement of 4 June 2008 in case No. SKC-377 changed the long-existing case law regarding including a contractual penalty for violation of professional activity restriction in the employment contract. ${ }^{69}$ In the aforementioned judgement, the Supreme Court has arrived at a conclusion that it follows from Article 84 of the Labour Law that agreement to restrict competition does not affect the legal situation of the employee during employment relationships, but it applies to time period after discontinuation of employment relationships - agreement on competition restriction comes in force when the employment contract is no longer in force and concurrently - when a person has lost the status of employee. ${ }^{70}$ Considering the aforementioned, the

67 Spinner, G. Kommentar zum Paragraph 611a des Bürgerliches Gesetzbuches, \$ 611a, Rn. 1155.

68 Latvijas Republikas Augstākās tiesas Senāta Civillietu departamenta 2008. gada 9. janvāra spriedums lietā Nr. SKC-6/2008 [Judgement of 9 January 2008 of the Department of Civil Cases of the Senate of the Supreme Court of the Republic of Latvia in case No. SKC-6/2008] (not published).

69 Latvijas Republikas Augstākās tiesas Senāta Civillietu departamenta 2008. gada 4. jūnija spriedums lietā Nr. SKC-377/2008 [Judgement of the Department of Civil Cases of the Senate of the Supreme Court of the Republic of Latvia of 4 June 2008 in case No. SKC-377/2008]. Available: http://www. at.gov.lv/ info/archive/department1/hronologiskaseciba/2008/ [last viewed 23.03.2021].

70 Ibid. 
Supreme Court concluded that, interpreting clauses 28 and 84 of the Labour Law as to their essence and content, agreement on restriction on competition must be recognised as an independent agreement, ${ }^{71}$ and contractual penalty can be added as a measure of reinforcement of liability. The Supreme Court in its judgement ruled that under the circumstances where the parties have consented without deceit, fraud or duress to the agreement with stipulated restrictions on professional activity after termination of employment relationships and by signing that agreement expressed their will to fulfil the liability, it is only reasonable to stipulate another measure to reinforce the liability. ${ }^{72}$ The court has argued the reasonableness of contractual penalty by stating that in a situation where agreement to restrict competition is declared legal, and it can be found that former employee has violated it, however, no civil sanctions are applicable, Article 84 of the Labour Law becomes merely a declarative provision and business interests of the employer remain unprotected. In this situation, the mentioned provision would actually lose its meaning. Departing from a presumption that inclusion of Article 84 in the Labour Law has allowed the legislator to operate with a particular intention, it must be admitted that it has reasonably allowed application of measures that reinforce liability. Considering the aforesaid, there are no grounds to believe that a contractual penalty cannot be a reinforcement of liability in agreement to restrict competition. ${ }^{73}$ For example, in Estonian Law on Employment Contracts it is stated expressis verbis that the parties are entitled to introduce contractual penalty in agreement to restrict competition. ${ }^{74}$

By including a contractual penalty, the employer must take into account that the contractual penalty must be commensurate with the provisions of competition restriction, the amount of compensation among other things. The Supreme Court has concluded that by recognising the restriction on competition as legal, the court has no grounds to declare that contractual penalty in this case cannot be a reinforcement of liability, however, the court could evaluate commensurability

71 Latvijas Republikas Augstākās tiesas Senāta Civillietu departamenta 2009. gada 11. marta spriedums lietā Nr. SKC-99/2009 [Judgement of the Department of Civil Cases of the Senate of the Supreme Court of the Republic of Latvia of 11 March 2009 in case No. SKC-99/2009]. In: Tiesu prakse lietās par individuālajiem darba strīdiem [Case law in cases of individual labour disputes], p. 39.

72 Latvijas Republikas Augstākās tiesas Senāta Civillietu departamenta 2008. gada 26. novembra spriedums lietā Nr. SKC-424/2008 [Judgement of the Department of Civil Cases of the Senate of the Supreme Court of the Republic of Latvia of 26 November 2008 in case No. SKC-424/2008]. In: Latvijas Republikas Augstākās tiesas Senāta Civillietu departamenta spriedumi un lēmumi 2008 [Judgments and decisions of the Department of Civil Cases of the Senate of 2008], pp. 465-474.

73 Latvijas Republikas Augstākās tiesas Senāta Civillietu departamenta 2008. gada 4. jūnija spriedums lietā Nr. SKC-377/2008 [Judgement of the Department of Civil Cases of the Senate of the Supreme Court of the Republic of Latvia of 4 June 2008 in case No. SKC-377/2008]. Available: http://www. at.gov.lv/ info/archive/department1/hronologiskaseciba/2008/ [last viewed 23.03.2021]; Latvijas Republikas Augstākās tiesas Senāta Civillietu departamenta 2008. gada 26. novembra spriedums lietā Nr. SKC-424/2008 [Judgement of the Department of Civil Cases of the Senate of the Supreme Court of the Republic of Latvia of 26 November 2008 in case No. SKC-424/2008]. In: Latvijas Republikas Augstākās tiesas Senāta Civillietu departamenta spriedumi un lēmumi 2008 [Judgments and decisions of the Department of Civil Cases of the Senate of 2008], pp. 465-474; Latvijas Republikas Augstākās tiesas Senāta Civillietu departamenta 2009. gada 11. marta spriedums lietā Nr. SKC-99/2009 [Judgement of the Department of Civil Cases of the Senate of the Supreme Court of the Republic of Latvia of 11 March 2009 in case No. SKC-99/2009]. In: Tiesu prakse lietās par individuālajiem darba strīdiem [Case law in cases of individual labour disputes].

74 Employment Contracts Acts, Art. 26. Available: https://www.riigiteataja.ee/en/eli/520062016003/ consolide [last viewed 02.04.2021]. 
of the contractual penalty with provisions of competition restriction. ${ }^{75}$ It must be admitted that a contractual penalty may be included and deemed valid only provided that restrictions on professional activity are recognised as reasonable and lawful, and if the scope of contractual penalty complies with Article 1717 of CL that a contractual penalty must be commensurate and comply with fair business practice.

An obligation to pay a contractual penalty will be binding on the employee if the employer can prove the fact of violation of competition restriction (that is to say, the employer must not prove the resulting loss). As demonstrated by the analysis of Latvian case law, where an employee has violated a restriction on competition, former employers most often address the court with a request to reimburse the compensation paid for compliance with competition restrictions and contractual penalty and interest set by law, as well.

In several countries, in order to protect employer's interest in case of violation of restriction on competition, a special measure is employed - a provisional regulation which is, in fact, a court decision whereby the former employee is bound to an obligation to discontinue the competing business. Such claims are given noticeably short term of examination and therefore the former employer is efficiently protected before the violation of the employee has managed to greatly harm reasonable interests of the former employer. ${ }^{76}$ However, while this provisional regulation is not provided for in Latvian laws and regulations, the contractual penalty is deemed to be the most efficient mechanism to protect interests of the former employer.

Interesting and rather beneficial from the perspective of employee's interests is, for example, the regulation existing in Netherlands, according to which an employee who wishes to start employment relationships or run a business that could potentially lead to violation of competition restriction may bring an action to the court in advance (a priori) and request to provide an evaluation in a form of a decision about compliance of this activity with provisions of the agreement. ${ }^{77}$ Therefore, this regulation helps employees to avoid potential obligation to compensate for losses or pay contractual penalty to former employer in future.

75 Latvijas Republikas Augstākās tiesas Senāta Civillietu departamenta 2008. gada 4. jūnija spriedums lietā Nr. SKC-377/2008 [Judgement of the Department of Civil Cases of the Senate of the Supreme Court of the Republic of Latvia of 4 June 2008 in case No. SKC-377/2008]. Available: http://www.at.gov.lv/ info/archive/department1/hronologiskaseciba/2008/ [last viewed 23.03.2021]; Latvijas Republikas Augstākās tiesas Senāta Civillietu departamenta 2009. gada 11. marta spriedums lietā Nr. SKC-99/2009 [Judgement of the Department of Civil Cases of the Senate of the Supreme Court of the Republic of Latvia of 11 March 2009 in case No. SKC-99/2009]. In: Tiesu prakse lietās par individuālajiem darba strīdiem [Case law in cases of individual labour disputes], p. 39.

76 Azanda, I., Kravale, S. Konkurences ierobežojumi darbiniekam, kapitālsabiedrības amatpersonai un dalībniekam pēc tiesisko attiecību izbeigšanās: Darba likuma un Konkurences likuma regulējums [Restrictions of competition for an employee, an official of a capital company and a participant after the termination of legal relations: Regulation of the Labor Law and the Competition Law]. In: Zinātniskie raksti 2012 [Scientific Papers 2012]. Rīga: RSU, 2013, p. 86.

77 Lagesse, P., Norrbom, M. Restrictive Covenants ..., p. 181. 


\section{Unilateral Withdrawal from the Restriction on Competition}

\subsection{Employer's Rights to Unilaterally Withdraw from the Restriction on Competition}

Employer's rights to unilaterally withdraw from the restriction on competition are based on loss of his legal interest. The competition becomes senseless without a legal interest in preventing undesirable competition and therefore the employer may free himself from an obligation to pay compensation, at the same time allowing the employee to choose next workplace at his or her own consideration.

An issue on employer's rights to unilateral withdrawal from the agreement to restrict competition led to different opinions in the doctrine and case law, so in 2017 amendments were made to paragraph 1 of Article 85 of the Labour Law and currently this provision states that "If an employer gives a notice of termination, the employer may unilaterally withdraw from an agreement on the restriction on competition only prior to giving the notice of termination or concurrently with it, but in other cases of terminating employment relationships - prior to the termination of the employment contract." That way, the clause differentiates time until which an employer enjoys these rights depending on the type of termination of employment relationships. If the employer gives notice of termination to the employer at own initiative, he may inform the employee on withdrawing from the agreement to restrict competition only before the notice or on the moment of submission. Meanwhile, in other cases the employer must notify on withdrawal from the agreement to restrict competition before termination of the employment contract. As follows from the documentation substantiating amendments to the draft law, other cases are usually understood to be mainly mutual agreement of parties and notice given by the employee. ${ }^{78}$ Thus, also in cases where an employee gives a notice, the employer could withdraw from the agreement for the entire period of notice until the moment the employment relationships are actually ended. Once the employment relationships between the employer and employee are terminated, the restriction on competition could be ended only upon mutual agreement of the parties.

\subsection{Employee's Rights to Unilaterally Withdraw from the Restriction on Competition}

Employee's rights to unilaterally withdraw from the agreement to restrict competition are much narrower than those of employer. They are governed by paragraph 3 of Article 85. It states that an employee is entitled to unilaterally withdraw from the restriction on competition only if the notice is given due to important reason (i.e., paragraph 5 of the Labour Law provides for the notice given by the employee). Notion "important reason" included in paragraph 5 of Article 100 of the Labour Law is a general clause which designates a reason preventing an employee from continuing employment relationships due to ethical and fairness considerations. ${ }^{79}$ Pursuant to paragraph 5 of Article 100 of the Labour Law, the employee gives a notice of

78 Likumprojekta "Grozijjumi Darba likumā” sākotnējās ietekmes novērtējuma ziṇojums (anotācija) [Preliminary Impact Assessment Report of the Draft Law "Amendments to the Labour Law" (Annotation)], No. 968, p. 12. Available: http://titania.saeima.lv/LIVS12/SaeimaLIVS12.nsf/0/A135 21DACF3B0A70C2258154002231CC?OpenDocument [last viewed 02.04.2021].

79 Jonikāns, V. Darba likumā ietverto generālklauzulu aizpildīšana [Completion of general clauses included in the Labor Law]. Latvijas Republikas Augstākās Tiesas Biletetens, No. 6, April, 2013. 
termination if his subjective evaluation of given situation and circumstances leads him to a conclusion whereof he discontinues employment relationship due to ethical and moral considerations. In fact, such decision made by the employee essentially punishes the employer for his unethical, unjustifiable or even illegal conduct. ${ }^{80}$

Therefore, in compliance with paragraph 3 of Article 85 of the Labour Law, an employer may rely on the fact that the employee will be entitled to withdraw from the restriction on competition solely due to important reason. Besides, this reason essentially depends on employer's conduct. The employee, in his turn, is given an opportunity to free himself from an obligation to comply with the restriction on professional activity in relation to an employer who has compromised ethical and moral considerations. The employee must exercise his right to withdraw from the agreement on competition restrictions within one month of the day of notice, and he must submit such written notice to the employer. Nevertheless, a similar regulation of employee's rights to withdraw from the restriction on competition where the employment relationships were terminated due to conduct of the employer, exists also in Germany ${ }^{81}$, Finland ${ }^{82}$ and other countries.

For a comparison, it must be stated that in the neighbouring countries, Lithuania and Estonia, regulation of rights to unilaterally withdraw from the agreed restriction on competition has been elaborated more thoroughly. For example, a premise of Lithuanian Labour Code that an employee is entitled to unilaterally withdraw from the non-competition agreement if the employer has delayed payment of non-competition payments in whole or in part for more than two months, should be praised ${ }^{83}$.

Of course, even though it is not written in the Labour Law, the parties are entitled to enter in mutual agreement on cancellation of competition restrictions at any time.

\section{Summary}

1. An agreement to restrict competition, even if it is already integrated in the employment contract, is a separate agreement. The agreement enters into force as soon as the employment contract loses its force and the parties have lost their respective status of employer and employee. Unlike the legal employment relationships, it is possible to apply also a reinforcement of liability - contractual penalty - in performing this agreement.

2. At times, some suggestions in Latvian legal literature include a regulation in Article 84 of the Labour Law on the minimum amount of compensation which is to be paid during the competition restriction period. However, since

80 Latvijas Republikas Augstākās tiesas Senāta Civillietu departamenta 2015. gada 20. janvāra spriedums lietā nr. SKC-1793/2015 [Judgment of the Department of Civil Cases of the Supreme Court of the Republic of Latvia of 20 January 2015 in case No. SKC-1793/2015], para. 11. Available: http://www. at.gov.lv/downloadlawfile/2918 [last viewed 28.03.2021].

81 Thüsing, G. Kommentar zum $\$ \S 1-104$ a des Handelsgesetzbuch. In: Drescher, I., Fleischer, H., Schmidt, K. (Hrsg.). Münchener Kommentar zum Handelsgesetzbuch. Band 1. Erstes Buch. Handelsstand. \$\$ 1-104a. 5. Auflage. München: C. H. Beck, 2021, §75, Rn. 3.

82 Employment Contracts Act, Sect. 5. Available: https://www.ilo.org/dyn/natlex/natlex4.detail\%3Fp_ lang\%3Den\%26p_isn\%3D58905\%26p_classification\%3D12.01 [last viewed 19.03.2021].

83 Lietuvos Respublikos darbo kodeksas [Labour Code of the Republic of Lithuania]. Art 38(5). Available: https://eseimas.lrs.lt/portal/legalAct/lt/TAD/da9eea30a61211e8aa33fe8f0fea665f?position InSearchResults=0\&searchModelUUID=6a53d828-eda2-4945-a9fb-6ce37316f0cf\%20f [last viewed 19.03.2021]. 
the parties in Latvia can agree on very diverse restrictions on competition, including a very narrow restriction on competition (in terms of scope or place), not always there is a reason to pay the compensation amount which is stated by laws and regulations of other countries (for example, a rather common regulation on one third or half of the previous salary). Therefore, in order not to restrict possibilities of the parties to agree on a narrow restriction on competition in terms of scope, it is preferable to retain the existing regulation of the Labour Law, which states that compensation must be "adequate", and this notion should be given content in each individual case.

3. When determining the place of restriction on competition, one should follow reasonable criteria. For example, it would be reasonable to agree on wide territorial restrictions (attributing it to foreign countries), if the employer already runs business on that territory or plans to launch it there soon.

4. Paragraph 3 of Article 84 of the Labour Law states that "agreement to restrict competition is not valid to an extent it is deemed to be an unfair restriction of professional activity of the employee [..] considering the compensation to be paid out to employee." Considering that parties may integrate agreement to restrict competition already in the employment contract, it may, however, take long before the parties terminate the employment relationships and there is a possibility that the compensation agreed is no longer adequate for the updated market salary on the moment of termination of employment. Therefore, fairness of compensation for restriction on competition should be evaluated as at the time these restrictions are applied (i.e., when terminating employment relationships) rather than the situation at the moment of incorporating this agreement in the employment contract.

5. If the agreement to restrict competition is made upon establishing the employment relationship or during it, it is preferable to express compensation in percentage from the salary rather than a certain (fixed) sum which could be far from adequate compensation concept on the moment of termination the employment relationships considering a possible inflation.

6. Each country has its own regulation of restriction on competition with unique features, nevertheless, it can be concluded that in Latvia the restriction on competition is regulated in accordance with the ideas of a democratic state and elements of employment freedom integrated in the constitution. Amendments to the Labour Law of 2017 have improved legal framework of restriction on competition in a number of aspects and can be evaluated positively, however, there are several elements related to this instrument of law which could, possibly, be solved by Latvian courts or legislator, and examples from other countries may give useful insights in this regard.

\section{Sources}

\section{Bibliography}

1. Agreement on Non-Competition is Not Part of Employment Contract. Available: http://www. labourlawnetwork.eu/national_labour_law_latest_country_reports/national_court_rulings/ court_decisions/prm/64/v__detail/id_2927/category_10/index.html [last viewed 23.03.2021].

2. Azanda, I., Kravale, S. Konkurences ierobežojumi darbiniekam, kapitālsabiedrības amatpersonai un dalībniekam pēc tiesisko attiecību izbeigšanās: Darba likuma un Konkurences likuma regulējums [Restrictions of competition for an employee, an official of a capital company and a participant 
after the termination of legal relations: Regulation of the Labor Law and the Competition Law]. In: Zinātniskie raksti 2012 [Scientific Papers 2012]. Rīga: RSU, 2013.

3. Balodis, K. Ievads civiltiesībās [Introduction to Civil Law]. Rīga: Zvaigzne ABC, 2007.

4. Bevitt, A., La Tanya, J. U.S. and E.U. Non-Competition Agreements Compared and Contrasted. Available: http://documents.jdsupra.com/d5bb690a-135c-4a53-b61e-0740d11d8002.pdf [last viewed 25.03.2021].

5. Campbell, D. Post-Employment Covenants in Employment Relationships. Alphen aan den Rijn: Kluwer Law International, 2014.

6. Clifford Chance. Employment and Benefits in the European Union. London: Clifford Chance LLP, 2007.

7. Darba likums ar komentāriem [Labor Law with Comments]. Rīga: Latvijas Brīvo arodbiedrību savieniba, 2020.

8. Eylert, M. Non-Competition Clauses in Labour Contracts. Germany XIVth Meeting of European Labour Court Judges 4 September 2006. Available: http://www.ilo.org/wcmsp5/groups/ public/---ed_dialogue/---dialogue/documents/meetingdocument/wcms_159962.pdf [last viewed 12.03.2021].

9. Gailums, I. Darba likums. Komentāri. Tiesu prakse [Labour Law. Commentaries. Case Law]. $2^{\text {nd }}$ Book. Rīga: Gailuma juridiskā biznesa biroja izdevniecība, 2003.

10. Gomes Vieira, J. M., de Oliveira Carvalho, C. Labour Law in Portugal. Kluwer Law International, 2011.

11. Holland, J. A., Burnett, S. A. Employment Law. New York: Oxford University Press, 2008.

12. International Business Publications. Denmark Investment and Business Guide. Volume 1. Strategic and Practical Information. Washington: International Business Publications. USA, 2015.

13. Jonikāns, V. Darba likumā ietverto generālklauzulu aizpildīšana [Completion of general clauses included in the Labor Law]. Latvijas Republikas Augstäkäs Tiesas Biletens, No. 6, April, 2013.

14. Kuras, G. Non-Competition Clauses in Labour Contracts. Austria. XIV ${ }^{\text {th }}$ Meeting of European Labour Court Judges 4 September 2006. Available: https://www.ilo.org/wcmsp5/groups/public/--ed_dialogue/---dialogue/documents/meeting document/wcms_159958.pdf [last viewed 19.03.2021].

15. Lagesse, P., Norrbom, M. Restrictive Covenants in Employment Contracts and Other Mechanisms for Protection of Corporate Confidential Information. Alphen aan den Rijn: Kluwer Law International, 2006.

16. Mammone, G. Non-Competition Clauses in Labour Contracts. Italy. XIV $V^{\text {th }}$ Meeting of European Labour Court Judges 4 September 2006. Available: http://www.ilo.org/wcmsp5/groups/public/--ed_dialogue/--dialogue/documents/meetingdocument/wcms_159966.pdf [last viewed 19.03.2021].

17. Miller, R. L., Jentz, G. A. Fundamentals of Business Law: Excerpted Cases. $2^{\text {nd }}$ edition. Mason: South-Western Cengage Learning, 2009.

18. Novak, J. Prohibition of Competition and Non-Competition Clauses in Labour Contracts. Slovenia. XIV $^{\text {th }}$ Meeting of European Labour Court Judges 4 September 2006. Available: https://www.ilo.org/ wcmsp5/groups/public/@ed_dialogue/@dialogue/documents/meetingdocument/wcms_159970. pdf [last viewed 31.03.2021].

19. Osis, G. Konkurences ierobežojums pēc darba tiesisko attiecību izbeigšanās [Restriction of competition after termination of employment relations]. Riga: Latvijas Universitāte, 2019, pp. 22-23.

20. Pivateau, G. T. Putting the Blue Pencil down: An Argument for Specificity in Noncompete Arguments. Nebraska Law Review, Vol. 84, No. 3, 2008. Available: http://papers.ssrn.com/sol3/ papers.cfm?abstract_id=1007599 [last viewed 12.03.2021].

21. Rācenājs, $K$. Ierobežojumi pēc darba tiesisko attiecību izbeigšanās [Restrictions after termination of employment]. Jurista Värds, No. 39(492), 25.09.2007.

22. Selwyn, N. M. Selwyn's Law of Employment. 14 $4^{\text {th }}$ edition. Oxford: Oxford University Press, 2006.

23. Spinner, G. Kommentar zum Paragraph 611a des Bürgerliches Gesetzbuches. In: Henssler, M., Krüger, W. (Red.). Münchener Kommentar zum Bürgerlichen Gesetzbuch. Band 5. Schuldrecht. Besonderer Teil II. $\$ \$ 535-630$ h. 8. Auflage. München: C. H. Beck, 2020.

24. Storck, C. Non-Competition Clauses in Labour Contracts. Belgium. XIV th Meeting of European Labour Court Judges. September 2006. Available: http://www.ilo.org/wcmsp5/groups/public/---ed_ dialogue/---dialogue/documents/meetingdocument/wcms_159959.pdf [last viewed 12.03.2021].

25. Thüsing, G. Kommentar zum $\$ \$ 1-104$ a des Handelsgesetzbuch. In: Drescher, I., Fleischer, H., Schmidt, K. (Hrsg.). Münchener Kommentar zum Handelsgesetzbuch. Band 1. Erstes Buch. Handelsstand. $\$ \$ 1$ 1-104a. 5. Auflage. München: C. H. Beck, 2021. 
26. Valverde, A. M., Salmerón, B. R., Luque, L., García, F. F. Non-Competition Clauses in Labour Contracts. XIV $V^{\text {th }}$ Meeting of European Labour Court Judges 4 September 2006. Available: http:// www.ilo.org/wcmsp5/groups/public/---ed_dialogue/---dialogue/documents/ meetingdocument/ wcms_159971.pdf [last viewed 19.03.2021].

27. Viešūnaite, V. How to Conclude a Valid Lithuanian Non-Competition Agreement. Available: http:// triniti. ee/en/archives/4420 [last viewed 12.03.2021].

28. Weiss, M., Schmidt, M. Labour Law and Industrial Relations in Germany. Wolters Kluwer, 2007.

\section{Normative Acts}

1. Latvijas Republikas Satversme [The Constitution of the Republic of Latvia] (15.02.1922). Available: https://likumi.lv/ta/en/en/id/57980-the-constitution-of-the-republic-of-latvia [last viewed 25.03.2021].

2. Civillikums [The Civil Law] (28.01.1937). Available: https://likumi.lv/ta/en/en/id/225418-the-civillaw [last viewed 11.03.2021].

3. Grozījumi Darba likumā [Amendments in Labour Law] (27.07.2017). Available: https://likumi.lv/ $\mathrm{ta} / \mathrm{id} / 292584$-grozijumi-darba-likuma [last viewed 25.03.2021].

4. Darba likums [Labour Law] (20.06.2001). Available: https://likumi.lv/ta/en/en/id/26019-labour-law [last viewed 25.03.2021].

5. Employment Contracts Act of Estonia. Available: https://www.riigiteataja.ee/ne /eli/520062016003/ consolide [last viewed 31.03.2021].

6. Employment Contracts Act of Finland. Sect. 5. Available: https://finlex.fi/en/laki/kaannokset/2001/ en20010055.pdf [last viewed 31.03.2021].

7. On the Labor Code of Hungary. Available: http://www.ilo.org/wcmsp5/groups/public/--ed_protect/---protrav/---ilo_aids/documents/legaldocument/wcms_186075.pdf [last viewed 31.03.2021].

8. Labour Code of the Republic of Lithuania. Available: https://e-seimas.lrs.lt/ [last viewed 31.03.2021].

9. Portuguese Labour Code. Available: http://www.cite.gov.pt/pt/legis/CodTrab_L1_004.html\#L004S9 [last viewed 19.03.2021].

10. Gewerbeordnung. Available: https://www.gesetze-im-internet.de/gewo/ [last viewed 01.03.2021].

11. Bürgerliches Gesetzbuch. Available: https://www.gesetze-im-internet.de/bgb/ [last viewed 26.02.2021].

\section{Case Law}

1. Latvijas Republikas Augstākās tiesas Senāta Civillietu departamenta 2007. gada 29. augusta spriedums lietā Nr. SKC-560/2007 [Judgment of the Department of Civil Cases of the Senate of the Supreme Court of the Republic of Latvia of 29 August 2007 in case No. SKC-560/2007] (not published).

2. Latvijas Republikas Augstākās tiesas Senāta Civillietu departamenta 2008. gada 9. janvāra spriedums lietā Nr. SKC-6/2008 [Judgement of 9 January 2008 of the Department of Civil Cases of the Senate of the Supreme Court of the Republic of Latvia in case No. SKC-6/200] (not published).

3. Latvijas Republikas Augstākās tiesas Senāta Civillietu departamenta 2008. gada 4. jūnija spriedums lietā Nr. SKC-377/2008 [Judgement of the Department of Civil Cases of the Senate of the Supreme Court of the Republic of Latvia of 4 June 2008 in case No. SKC-377/2008]. Available: http://www. at.gov.lv/ info/archive/department1/hronologiskaseciba/2008/ [last viewed 23.03.2021].

4. Latvijas Republikas Augstākās tiesas Senāta Civillietu departamenta 2008. gada 26. novembra spriedums lietā Nr. SKC-424/2008 [Judgement of the Department of Civil Cases of the Senate of the Supreme Court of the Republic of Latvia of 26 November 2008 in case No. SKC-424/2008]. In: Latvijas Republikas Augstākās tiesas Senāta Civillietu departamenta spriedumi un lēmumi 2008 [Judgments and decisions of the Department of Civil Cases of the Senate of 2008]. Rìga: Latvijas Tiesnešu mācību centrs, 2009, 465. - 474.lpp.

5. Latvijas Republikas Augstākās tiesas Senāta Civillietu departamenta 2009. gada 11. marta spriedums lietā Nr. SKC-99/2009 [Judgement of the Department of Civil Cases of the Senate of the Supreme Court of the Republic of Latvia of 11 March 2009 in case No. SKC-99/2009. In: Tiesu prakse lietās par individuālajiem darba strīdiem [Case law in cases of individual labour disputes], 2010/2011. Available: http://at.gov.lv/files/uploads/files/docs/2011/individualie\%20darba\%20stridi.pdf [last viewed 19.02.2021].

6. Latvijas Republikas Augstākās tiesas Senāta Civillietu departamenta 2015. gada 20. janvāra spriedums lietā Nr. SKC-1793/2015 [Judgment of the Department of Civil Cases of the Supreme 
Court of the Republic of Latvia of 20 January 2015 in case No. SKC-1793/2015]. Available: http:// www.at.gov.lv/downloadlawfile/2918 [last viewed 28.03.2021].

7. Rìgas rajona tiesas 2013. gada 17. decembra spriedums lietā Nr. C33334313 [Judgment of the Riga District Court of 17 December 2013 in case No. C33334313] (not published and has not entered into force due to the concluded settlement).

8. Rigas rajona tiesas 2009. gada 18. decembra spriedums lietā Nr. C33287709 [Judgment of the Riga District Court of 18 December 2009 in case No. C33287709] (not published).

9. Rīgas apgabaltiesas Civillietu tiesas kolēgijas 2019. gada 15. aprịla spriedums lietā Nr. C32179317 [Judgment of the Chamber of Civil Cases of the Riga Regional Court of 15 April 2019 in case No. C32179317]. Available: https://manas.tiesas.lv/ [last viewed 01.04.2021].

10. Siguldas tiesas 2007. gada 14. februāra spriedums lietā Nr. C35045806 [Judgment of Sigulda court of February 14, 2007 in case No. C35045806] (not published).

11. Rīgas pilsētas Zemgales priekšpilsētas 2008. gada 6. marta spriedums lietā Nr. C31127906 [Judgment of the Riga City Zemgale Suburb Court of March 6, 2008 in the case No. C31127906] (not published).

12. Latvijas Republikas Augstākā tiesa. Tiesu prakse lietās par individuālajiem darba strīdiem [Supreme Court of the Republic of Latvia. Case law on individual labour disputes], 2011/2012. Available: http://at.gov.lv/files/uploads/files/docs/petijumi/darba\%20stridi.pdf [last viewed 12.03.2021].

13. Judgment of the Federal Supreme Labor Court of the Federal Republic of Germany of 1 August 1995 in case No. 9 AZR 884/93.

14. United States District Court, S. D. Texas, Houston Division. January 12, 2009. TransPerfect Translations, Inc. v. Leslie. Available: https://www.courtlistener.com/opinion/1902491/transperfecttranslations-inc-v-leslie/ [last viewed 02.04.2021].

\section{Other Sources}

1. Likumprojekta "Grozijumi Darba likumā" sākotnējās ietekmes novērtējuma ziņojums (anotācija) [Preliminary Impact Assessment Report of the Draft Law "Amendments to the Labor Law" (Annotation)], No. 968, p. 12. Available: http://titania.saeima.lv/LIVS12/SaeimaLIVS12.nsf/0/A13 521DACF3B0A70C2258154002231CC?Open Document [last viewed 02.04.2021].

2. Cik pamatoti no valsts līdzekḷiem tiek izmaksātas kompensācijas par profesionālās darbības ierobežojumu [How justified is compensation for restrictions on professional activity paid from state funds]? (23.03.2021). Available: https://www.lrvk.gov.lv/lv/covid-19/cik-pamatoti-no-valstslidzekliem-tiek-izmaksatas-kompensacijas-par-profesionalas-darbibas-ierobezojumu [last viewed 23.03.2021]. 